\title{
An Extensive Study: Preparation of People's Biodiversity Register (PBR) in Malkangiri District, Odisha
}

\author{
Subhashree Subhasmita ${ }^{1 *}$, Gyana Ranjan Mahalik², \\ Prasad Kumar Dash ${ }^{3}$ and Sangram Keshari Swain ${ }^{4}$ \\ ${ }^{1,2,4}$ Centurion University of Technology and Management, Odisha, India \\ ${ }^{3}$ Odisha Biodiversity Board, Odisha, India \\ Corresponding author email: subhashree3949@gmail.com
}

\section{ABSTRACT}

Biological Diversity Act, 2002 envisaged that every local body in India shall constitute a Biodiversity Management Committee (BMC) within its jurisdiction for the purpose of promoting conservation of biological diversity, sustainable use of its components and fair and equitable sharing of the benefits arising out of the commercial utilization of bioresources. The registers have opened new hope for local communities to get incentives against their conservation action. Poverty reduction, ecological infrastructure, risk reduction/mitigation and climate change, valuations of nature's contribution to human society and better management of the local resources are the other issues that can be addressed under the registers. Methods like Participatory Rural Appraisal (PRA), Focus Group Discussions (FGDs), Personal Interviews (PIs), Key Informants (KIs), Review of published literatures like district working plan, published research papers/research reports, review of district web portals of all the government line departments and collection of primary field data are followed to document the PBR. Due to the presence of no. of primitive tribal groups like Bondas, Gadabas, Kondhs and Koyas, the indigenous knowledge related to application of bio-resources in human welfare is still prevailing in most part of the district which is reflected in the present PBR document.

KEY WORDS: BMC, MITIGATION, KEY INFORMANTS, BONDAS.

\section{INTRODUCTION}

Under a multilateral environment agreement, to protect and conserve the loss of biodiversity, the Convention on Biological Diversity (CBD) was signed by 193 countries in 1992 and India as a signatory to CBD, developed its National Biodiversity Strategies and Action plan. The Government of India notified the "Biological Diversity Act in the year 2002 and the "Biological Diversity Rules" were framed in 2004. The main objectives of the Act are Conserve Biological Diversity, sustainable use of its component and fair and equitable sharing of the benefits arising from its use. With this enforcement, the Government of Odisha has constituted the Odisha Biodiversity Board in the year 2009 and "Odisha

Biosc Biotech Res Comm P-ISSN: 0974-6455 E-ISSN: 2321-4007

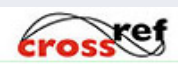

Identifiers and Pagination

Year: 2021 Vol: 14 No (9) Special Issue

Pages: 01-05

This is an open access article under Creative

Commons License Attribn 4.0 Intl (CC-BY).

DOI: $h t t p: / / d x$.doi.org/10.21786/bbrc/14.9.1
Biological Diversity Rules” were framed in 2012 (research gate).

1.2 The Biological Diversity Act, 2002 and People's Biodiversity Registers: With the the enactment of Biological Diversity Act, 2002, the goal of establishing people's rights over their natural resources and their involvement in its protection and conservation is put in place. Various efforts are being made countrywide for documenting the local biodiversity. Although there are defined formats for data collection, a systematic approach for the local community to develop the People's Biodiversity Register (PBR) was required. Without this, there was a lack of ownership. This manual is an attempt to bridge this gap. To execute legal implementation of the Act to empower the local bodies to exercise their right on protection and conservation of bioresources including preparation of PBRs, three statutory bodies were formed through a three-tier system. At National level national Biodiversity Authority (NBA) was established in Chennai under section 8, state biodiversity boards (SBBs) and Union Territory Councils (UT Councils) were formed at state level under section 22 and Biodiversity Management
Article Information

Received: $10^{\text {th }}$ Apr 2021

ccepted after revision: $15^{\text {th }}$ June 2021 
Committees (BMCs) were formed at local body level under section 41. The methodology and manuals for developing the PBRs was designated by National Biodiversity Authority (NBA) of India.

1.3 People's Biodiversity Registers and the role of the Biodiversity Management Committees: Every local body shall constitute a Biodiversity Management Committee (BMC) within its area for the purpose of promoting conservation, sustainable use and documentation of biological diversity including preservation of habitats, conservation of land races, folk varieties and cultivars, domesticated stocks and breeds of animals and microorganisms and chronicling of knowledge relating to biological diversity. The mandate of the Biodiversity Management Committee has been clearly highlighted in the Biological Diversity Act, 2002 as follows: As per Section 22 (6) of Biological Diversity Rules, 2004 "The main function of the BMC is to prepare People's Biodiversity Registers (PBRs) in consultation with local people. The Register shall contain comprehensive information on availability and knowledge of local biological resources, their medicinal or any other use.

- The other functions of the BMC are to advice on any matter referred to it by the State Biodiversity Boards or Authority for granting approval, to maintain data about the local vaids and practitioners using the biological resources.

- The Authority shall take steps to specify the form of the People's Biodiversity Registers, and the particulars it shall contain and the format for electronic database.

- The Authority and the State Biodiversity Boards shall provide guidance and technical support to the Biodiversity Management Committees for preparing People's Biodiversity Registers.

- The People's Biodiversity Registers shall be maintained and validated by the Biodiversity Management Committees.

1.4 People's Biodiversity Registers and the role of National Biodiversity Authority (NBA): Biodiversity Management Committee (BMC) for preparing People's Biodiversity Register.

1.5 People's Biodiversity Registers and Role of the Technical Support Group (TSG): The Technical Support Group (TSG) will consist of experts from various disciplines and line departments, universities, research institutes, colleges and schools and non-governmental organizations. The Technical Support Group will provide technical inputs and advice to the BMCs on identification of plants and animals, monitor and evaluate the PBR exercise, examine confidential information and advice on legal protection, maintain a database of local and external experts on biodiversity.

2.1 People's Biodiversity Registers (PBR): PBR is a document which contains comprehensive information on locally available bioresources including landscape and demography of a particular area (springer.com).
The PBR is an authentic document prepared by the state biodiversity boards and UT Councils in their vernacular language chronicling the local biodiversity of their cultural landscapes at Panchayat, Municipal Corporation and other urban area level in a participatory manner with prior informed consent (PIC) of the local community. The register records people's knowledge and ongoing changes in biodiversity of the area and serves as a baseline database for future management strategies and it is considered as a handbook for assessing locally significant elements of biodiversity and TK. The registers can serve as an instrument to understand appropriate components in designing conservation efforts. The PBR can also protect intellectual property rights (IPR) of local communities as it is a database of traditional knowledge (TK) and intellectual properties (IP) of local tribal and rural communities on biological resources.

\subsection{Relevance OF PBR: \\ The PBRs will help in;}

- Chronicling the depleting indigenous traditional knowledge at all local bodies across the entire Indian subcontinent.

- Declaration of Biodiversity Heritage Sites (BHS).

- Conservation of threatened and endemic plants and animal species of the area falling within its territorial jurisdiction.

- Long term strategies for biodiversity conservation.

- Increasing the livelihoods of the local community who are depending on the biodiversity and assisting in poverty reduction.

- Documentation of potential biodiversity for Access and Benefit Sharing (ABS) mechanisms.

- Effective management, promotion and sustainable uses of bioresources.

- Protection of rights including IPR over Biological resources and associated knowledge and systems.

- Impose restriction/regulations towards access to the flora and fauna which are threatened, and endemic.

- Restrict the activities which cause genetic erosion affecting the species and ecosystems.

1.2 Review of Literature: After 16 years since the enactment of Biological Diversity Act, its implementation remained dismal. In July 2016, a petition was filed by a Pune-based activist Chandra Bhal Singh before the National Green Tribunal (NGT) for effective implementation of the BD Act, 2002. At the time of filing the petition, out of 2,70,573 local bodies across the country, only 9,700 had a BMC; thereby implying compliance at a mere 3.58 percent. In terms of PBRs, 1,388 out of 9,700 BMCs had managed to complete the same; which means compliance of 14.31 percent. Given the tardy progress made by India's cornerstone biodiversity legislation even after 13 years of its being in force, the petitioner sought the intervention of the NGT to ensure compliance with the Act. Since then there have been a series of orders leading to significant movement in the case. Due to the NGT order, there has been a significant improvement in the formation of Biodiversity Management Committees and People's 
Biodiversity Registers which are important for the implementation of the Act.

Till date 2, 62,138 BMCs and 1, 90,950 PBRs have been prepared in all the states and Union Territories of India at Gram Panchayat, Pancahyat Samiti, Block, Districts, Municipal Corporation and other urban area level by State Biodiversity Boards and UT Biodiversity Councils. States viz. Assam (2549), Goa (205), Haryana (6437), Kerala (1034), Madhya Pradesh (23557), Punjab (13599), Sikkim (196), Tamil Nadu (13604), Tripura (1264) and Uttarakhand (1264) which have completed the constitution of BMC and preparation of PBRs in their respective local body level, states like Jharkhand and Telangana are on the verge of completing the process.

In Odisha till date the board has constituted 6952 BMCs at gram panchayat block, district and urban area level out of 7256 local bodies and prepared 181 PBRs at gram panchayat level and 30 PBRs at district level. Even though BMCs are constituted by UTs, no PBRs are yet to be prepared by them. Odisha Biodiversity Board is now in a mission to complete the preparation of PBRs and inviting assistance from Panchayat Raj department, leading civil society organizations of the state and scholars of universities to accomplish 100\% results in this direction.

\section{PBR Methodology:}

- One of the first steps for preparing a PBR is to organize a group meeting at unit level (Panchayat Raj Act 1994) to explain the objectives and purpose of the exercise.

- Different social groups in the village need to be identified for purpose of data collection from those groups

- Facilitators/TSG will collect the information from all sectors of biodiversity and ecosystem with intensive and extensive consultation with the people.

- The objectives and purpose is to be explained in a group meeting in the presence of all sections of people in the Panchayat, members of the BMC, students, knowledgeable individuals and all those interested in the effort.

- Documentation includes photographs (including digital images), drawings, audio and video recordings and other records like printed material, FGD, PRA, PI, KI etc.

Following methods were applied to document the PBR:

- Interviews of knowledgeable individuals, for instance, of changes in the availability of a medicinal plant species in the locality;

- Group interviews, for instance, as to who the gainers and losers are of a particular regime of management, for example, joint forest management of a forest patch;

- Field observations, for instance, of occurrence of a certain species of medicinal plant in a specific patch of forest, or the depth of water at a particular sampling location in a stream;
- Official documents, for instance, as to the amount realized by auctioning the rights to catch fish in a pond.

Following approach was adopted to documentation of Traditional Knowledge (TK) related to biodiversity in PBR: Every effort was made to identify the persons with proven knowledge of local biodiversity. Special attention was given to the elderly persons who can also provide information on the biodiversity which was available in the past but are no longer seen at present. In some cases focus group discussions were held for the purpose of documentation. The Vaidyas, Hakims, Disharies, NTFP collectors, Fisher folks, Grazing men/women, hunters, cultivators of indigenous verities, etc. were consulted thoroughly.

\section{Process in PBR Preparation;}

Step 1

Formation/Constitution of BMC

Step 2

Sensitization of the public about the study, survey and possible management

Step 3

Training of members in identification and collection of data on biological resources and traditional knowledge Step 4

Collection of data includes review of literature on the natural, resources of the districts, Participatory Rural Appraisal (PRAs) at village level, house hold interviews, individual interviews with village leaders and knowledgeable individuals, household heads, key actors of the panchayat raj institutions and NGOs and direct field observations.

Step 5

Analysis and validation of data in consultation with technical support group and BMC

Step 6

Preparation of People's Biodiversity Register (PBR)

Step 7

Computerization of information and resources

As per the revisited guidelines issued by the NBA in 2013 of 2009, the format of PBR consists brief profile of the local bodies (GPs/Block/NACs/Municipality/District. The general details include Annexure 1-5 and the PBR has 3 parts.

\section{Part I}

1. The Biological Diversity Act, 2002 \&t Rules, 2004

2. Peoples Biodiversity Registers and the role of the BMC.

3. Peoples Biodiversity Registers and the role of NBA

4. PBRs and the role of State Biodiversity Board

5. PBR and role of the Technical Support Group

6. The PBR Process

7. PBR methodology

8. Documentation of Traditional Knowledge related to biodiversity

\section{Part II}

There are 32 different formats to be filled up in different 
discipline for entire PBR preparation (Agro biodiversity, Domesticated Biodiversity, Wild Biodiversity, Urban Biodiversity)

\section{Part III}

Basically, covers the guide to field studies

Profile of the district: Malkangiri District is named after its headquarters town, Malkangiri. During formation of Odisha Province in 1936, Malkangiri was a 'Taluk' of Nabrangpur sub-division of Koraput District of Odisha. In 1962 it was upgraded to a subdivision of Koraput District. The present Malkangiri got its identity as an independent district due to reorganization of districts of Odisha as per a notification on 1st October, 1992 and with effect from 2nd October 1992. The Malkangiri district situated between $17^{\circ} 45^{\prime}$ to $18^{\circ} 40^{\prime} \mathrm{N}$ latitude and $81^{\circ} 10^{\prime}$ to $82^{\circ} 00^{\prime}$ E longitudes in southernmost part of Orissa state, India. This district is spread over an area of $5791 \mathrm{~km} 2$ with a maximum north-south elongation of $137 \mathrm{~km}$ and a maximum east-west elongation of $76 \mathrm{~km}$. The district is bounded in the east by Koraput district (a portion) of Orissa, Visakhapatnam and East Godavari districts of Andhra Pradesh, Bastar district of Chhattisgarh in the west, Koraput district of Orissa in the north and East Godavari and Khammam districts of Andhra Pradesh in the south.

\section{Peoples' Biodiversity Register (PBR): General Details}

Name of the District: Malkangiri

State: Odisha

Geographical Area: $5791 \mathrm{~km} 2$

Population: Total: 6,13,192

Male: 3, 03,624 Female: 3, 09,568

Habitat and Topography: The general topography of the area is of broken mountains intercepted by large riverbeds and watercourses. The altitude varies from $400 \mathrm{~m}$ near western side to $1200 \mathrm{~m}$ on the eastern side with mountain peaks and ridges. Numerous hill streams drain into major rivers such as Sabari, Sileru, Potteru, Kolab and Machhkund. Mainly black soil, which is rich in organic matter, occurs in this district. The climate of the major portion of the district is influenced by its varied elevation. The hill system descends into the low lying tracts of Malkangiri, about $1200 \mathrm{~m}$ altitude at their northern end and gradually falling away in a south-westerly direction to $200 \mathrm{~m}$ high at Motu, the extreme south-western corner of the district. Due to various anthropogenic active-ties, the forest cover of Malkangiri district now faces a threat of extinction. Slash and burn (locally known Podu) cultivation carried out by tribal people is the main cause of deforestation and land degradation in the district. With increase in human and animal population, the pressure on land has increased tremendously and much of the valley areas have been laid bare.

Climate (Rainfall, Temperature and other weather patterns) Land Use (Nine-fold classifications available with village records): December is the coldest part of the year with an average daily minimum temperature of 11.2. The maximum temperature seldom touches 43 in summer. Humidity is generally high especially in the monsoon and post monsoon months. It receives about 1400-2000 mm rainfall annually. Date, Month and Year of PBR preparation: July, 2020 Management Regime: Reserve Forests (RF) / Joint Forest Management (JFM) / Protected Areas (PA) / Community Owned and Managed Forests (COM)

\section{CONCLUSION}

The BMCs have been assigned with the responsibility of documentation of biodiversity and associated knowledge within their jurisdiction in the form of People's Biodiversity Registers (PBR). As BMCs will have the authority to levy charges on the individuals, traders, manufacturers, companies etc, against the commercial collection of the biological material, and would be consulted by SBBs and NBA while deciding on access to biological material and associated knowledge from the areas under their jurisdiction, an integrated and coordinated effort of all the three statutory bodies may lead to conservation of biodiversity and poverty reduction, Such complete document shall help the local sustainable resource management in restoration of wild relative of crop plants, traditional fishes, land races, folk verities, breeds of domesticated animals, wildlife habitats, other biologically significant areas like regional biodiversity rich sites, sacred groves and locally threatened wild species and supports claims of local ownership of biodiversity \& restoration of indigenous traditional knowledge and contributes to Knowledge flow.

\section{REFERENCES}

www.researchgate.net.

https://www.journals.elsevier.com/journal-for-natureconservation.

http://nbaindia.org/uploaded/pdf/PPT_PBRs_ Guidelines.pdf.

http://wgbis.ces.iisc.ernet.in/biodiversity/sahyadri_ enews/newsletter.

http://hpbiodiversity.gov.in.

https://link.springer.com.

https://www.keralabiodiversity.org/people-sbiodiversity-management-committee/people-sbiodiversity-register.

https://www.academia.eduPeople_Biodiversity_ Register_Documenting_biodiversity_for_natural_ resource management.

https://www.insightsonindia.com/biodiversitymanagement-committees-bmc/.

https://asbb.assam.gov.in/frontimpotentdata/ biodiversity-management-committees-bmcs.

http://environment.rajasthan.gov.in/content/ environment/en/rajasthan-state-biodiversity-board/ management/biodiversity-management-committees. 
html.

ethno botany of gadaba tribe of malkangiri.

https://www.downtoearth.org.in/news/agriculture/ this-odisha-tribe-grows-20-crop-varieties-withoutjeopardising-biodiversity..

https://www.vasundharaodisha.org. http://www.indianforester.co.in/index.php/ indianforester/article.

https://odishaahvs.nic.in/upload/files/Livestock Biodiversity Odisha.pdf

http://www.indiaenvironmentportal.org.in/files/ ReportofBiodiversityofSouthOrissa.pdf http://shodhganga.inflibnet.ac.in/publication.pdf 